\title{
A COMPARATIVE ANAL YSIS OF FINANCIAL PERFORMANCE OF NON-BANK FINANCIAL INSTITUTIONS IN BANGLADESH
}

\author{
S. M. Akber \\ Lecturer \\ Department of Business Administration \\ Ranada Prasad Shaha University, Bangladesh \\ M.Phil Researcher \\ Department of Finance, Jagannath University, Bangladesh \\ E-mail: akber@rpsu.edu.bd \\ (Dhttps://orcid.org/0000-0002-0267-3626 \\ Dhiman Barua \\ Assistant Professor \\ Faculty of Business Administration \\ BGC Trust University Bangladesh, Bangladesh \\ M.Phil Researcher \\ Department of Finance, Jagannath University, Bangladesh \\ E-mail: dhiman@bgctub.ac.bd
}

Received: October 01, 2021 Accepted: October 30, 2021 Online Published: November 26, 2021

DOI: 10.46281/amfbr.v6i1.1455

URL: https://doi.org/10.46281/amfbr.v6i1.1455

\begin{abstract}
NBFIs play an important role in economic development through ensuring proper mobilization of funds in Bangladesh. This study represents a comparison of nine NBFIs operating their business in Bangladesh within the period from 2016 to 2019 through using financial ratios and other measures. To analyze the financial performance this study has used ratio analysis, such as ROA, ROE, ROCE, Institutional sizel Total assets and total equity etc. The outcome of this study says that for generating return the NBFIs performance based on efficiency ratio is different from the performance based on liquidity ratio, capital ratio and other financial measures. This study suggests to NBFIs to be more conscious about loan selection and establish a brand image through providing more efficient services. It also suggests the NBFIs to finds more income generating areas to be more competitive. In the coming years NBFIs will have more prospects that will ensure the economic development of our country.
\end{abstract}

Keywords: NBFIs, Financial Performance, Efficiency, Liquidity, Profitability, ROA, ROE, ROCE.

JEL Classification Codes: F36, L25, G23. 


\section{INTRODUCTION}

An efficient financial system is essential to ensure economic development for any nation because it ensures a smooth transfer of fund from the surplus to deficit unit. To ensure an interruption free production, keeping the market competitive and assist the economic transaction properly a well-functioning financial system has no substitute. An efficient financial system means allocating the resources efficiently. It is the foundation of enhancing the performance of the organizations. Non-bank financial institutions are a part of the financial system. Through serving the economy, it ensures the economic development of a country. NBFI supports the economy through investment in the capital market, entrepreneurs' by giving short term or long term loans and through providing many other activities. Asset management (AM), institution size (IS), and operating efficiency three principal factors are important for enhancing the financial performance (Miskhin, 2019).

Non-bank financial institutions (NBFI) plays an important role in the financial sector of a country. There could be various institutions that act a NBFI but this paper works with finance companies. Finance companies are a part of NBFI. They don't collect a deposit like banks. They raised funds through selling their shares and invest the funds through providing direct and indirect loans. They also invest a portion of the funds in the capital market. That's why finance companies play a significant role in the performance of capital markets. Most of the finance companies are vertically integrated organizations. They are incorporated with various services such as merger and acquisition, advisory services, capital raising services, securities trading services, and research coverage (Madura, 2018).

The purpose of this study is to analyze the financial performance of the selected NBFI in Bangladesh within the period of 2016-2019.

To measure the performance, financial ratios and financial measures that have an impact over the performance of NBFI are used as a basis. So evaluating the financial performance of NBFI and comparing the relative market position of the selected NBFI in Bangladesh is the prime objective of this study. To measure the financial performance several ratios such as return on equity (ROE), return on assets (ROA), institution size/ total assets \& total equity, earnings per share (EPS), current ratio, capital ratio, return on capital employed (ROCE), and Interest Coverage Ratio are used. This study will analyze the financial performance of selected finance companies (NBFI) in Bangladesh. Then, based on the result it will identify their competitive position in Bangladesh. It also involves the managers and investors with important information about operating efficiency of finance companies so that it would be helpful for them to take decision for future development and investment.

\section{LITERATURE REVIEW}

Usually financial ratios, measuring performance against budget, benchmarking are used to measure the financial performance of any financial institutions (Avkiran, 1995). Through published financial statement one can get different types of ratios and it helps to determine the financial performance of that company. In Pakistan to classify financial institutions based on their performance different types of financial ratios such as return on equity (ROE), return on assets (ROA), total assets, total equity, earnings per share (EPS), current ratio, capital ratio, return on capital employed (ROCE), and administration expenses to profit before tax ratio are used (Ali Reza, 2011). Several studies have been conducted that are relevant to analyzing the company's performance that focus the operational effectiveness and efficiency to ensure the development of the company. 
Tarawneh (2006) conduct a research and came with an outcome that having better efficiency a company may not have a better effectiveness always. Elizabeth. D (2004) suggested through his study that the financial measures of performance, such as return on equity (ROE), capital adequacy ratio (CAR) and net interest margins (NIM) should be calculated positively with scores of customer service quality. Alsamaree (2013) worked in the same area within the period from 2007- 2010 based on the commercial banks of Kuwait. In his study he showed that because of distributing the profits properly banks in Kuwait were able to overcome the crisis and was able to draw the attention of National Bank of Kuwait.

Almumani (2014) made a research to analyze and compare the performance of Saudi banks listed in their stock market for the period 2007-2011. He measured the financial performance by two approaches such as trend analysis and inter-firm analysis. He came up with an outcome that Saudi Banks' profitability increase, due to increase of their operating income and their profitability decrease due to increase their assets, operating expense and cost of income. He also came up with an outcome that Saudi joint venture banks are more efficient to generate profits, absorb loan losses and to dominate in ROE. But the Saudi established banks are more capable to absorb asset losses and to dominate in ROA.

Akber (2019) conducted a research on the relationship between profitability and nonperforming loan on sharia based banks of Bangladesh. He used a sample of five sharia based banks in Bangladesh where return on equity was used as a proxy for profitability. He came up with an outcome that a consciousness of the authority on loan disbursement will lead to reduce the non-performing loan and increase the bank's profitability. Akber (2020) conducted another research on comparing the performance of traditional private commercial banks and Islamic banks in Bangladesh. He used a sample of five traditional commercial private banks and five Islamic banks and the performance were measured based on camels. He came with an outcome that in term of management quality private commercial banks perform better while in term of capital adequacy and liquidity position Islamic banks perform better.

Fukuyama (1995) researched among countries in Asia, to employ DEA and to analyze banking efficiency. In his research, he considered the efficiency of 143 Japanese banks as a sample. He came up with an outcome that the pure technical efficiency to average around $86 \%$ and scale efficiency around $98 \%$. It means that the major source of overall technical inefficiency is pure technical inefficiency. He said that the scale inefficiency is because of increasing returns to scale. He also said that banks with different organizational status perform differently and the scale efficiency is positively but weakly associated with bank size.

Tandon et al. (2019) conducted a research in the same field. In his research he showed non-performing loans and their impact on bank profitability. He focused on banks' specific macroeconomic determinants. Finally, he came with an outcome that to increase the profitability more attention is required for NPL management.

An efficient financial system reduces liquidity risk and it is done through a proper combination of different types of illiquid assets and proper securitization. Usually the presence of financial intermediary reduces information asymmetries and transaction cost. Through investment banks convert their liquid short-term assets to long-term illiquid investments (Diamond, 1983). Here the financial comparison of NBFIs in Bangladesh is based on return on equity (ROE), return on asset (ROA), institution size (IS) and many other activities.

Based on the above discussion, it can be said that most of the research worked with the banks or investment banks. A very few works have done with NBFIs which contributes a significant portion to the economic development of our country. So a research gap has created. 
That's why this study deals with the NBFIs and tries to analyze a comparative financial position of NBFIs in Bangladesh.

\section{OBJECTIVES OF THE STUDY}

The prime objective of this study is to analyze the financial performance of the finance companies (NBFI) in Bangladesh to ensure growth and prosperity of this sector. So the specific objectives of this study are to provide the insights of performance of the selected finance companies (NBFI) in Bangladesh. Based on the performance their competitive position will be analyzed. So that it will be helpful for the investor as well the management for taking the right decisions.

\section{RATIONALE OF THE STUDY}

This study is important because it will improve the NBFIs financial performance in Bangladesh. So it will contribute to the economic growth of Bangladesh. The worldwide growth of NBFIs and its impact over the economy gives is a clear indication how much it is important in Bangladesh economy. The reasons inspires to analyze this issue in Bangladesh.

\section{METHODOLOGY}

This study followed a quantitative research method to bring the best outcome. Most of the data used to analyze the performances are secondary data. It also used a comparative study of the NBFIs based on their individual financial performances.

Sample Size \& Sources of Data: The data used in this study consists of nine finance companies (NBFI) that are listed on the Dhaka Stock Exchange. So the sample size is nine. The duration for analyzing the data is the period from 2016-2019. These data are collected from the company's annual report as well from their websites.

Indicators for Performance Measurement: To measure the financial performance the following ratios are used:

- Profitability ratios: Return on equity (ROE), Return on Assets (ROA), Admin Expenses to Profit before Tax Ratio, Earnings per Share (EPS), and Return on Capital Employed (ROCE).

- Liquidity Ratio: Current Ratio

- Leverage ratio: Capital Ratio

- Institution Size: Total Assets, Total Equity

\section{RESULTS AND DISCUSSIONS}

To get a sound outcome of the financial performance analysis this study used time series data analysis for different types of ratios such as ROA, ROE, ROCE, Interest Coverage Ratio, Current Ratio, and Capital Ratio and measures their result. The results with discussion are as follows.

Return on Asset (ROA): The term return on asset means how much return is generated from using one unit of assets. It denotes the earning capacity of the NBFI by using its assets (Rose, 2016). It is calculated dividing net income by total assets. The calculated results for ROA shows IDLC generates the highest ROA (13.46) and PLFSL generates the lowest ROA (3.57) for their 
shareholders and overall it has an increasing trend from 2016 to 2019. It indicates a good earning capacity for NBFIs [see Appendix Table-01].

Return on Equity (ROE): Return on equity is an indicator to measure the financial performance of a company (Rose, 2016). It is calculated dividing net income by shareholders' equity. Here the calculated result for ROE shows IDLC generates the highest ROE (14.22) and PLFSL generates the lowest ROE (4.63) for their shareholders and overall it has an increasing trend from 2016 to 2019. It indicates a good sign for NBFIs. [See Appendix Table-02].

Return on Capital Employed (ROCE): The term return on capital employed is a financial ratio used to assess a company's profitability and efficiency of using capital (Rose, 2016). It helps to understand how well a company is generating profits from its using capital. Here the calculated result for ROCE shows that IDLC generates the highest ROE (17.04) and PLFSL generates the lowest ROE (7.15) and overall it has an increasing trend from 2016 to 2019. It is a good indication for NBFIs. [See Appendix Table-03].

Earnings per Share (EPS): The term earnings per share means how much earning the company is generating against each share. It measures the operating efficiency of a company (Besley, 2017). Here the calculated result for EPS shows that GSPFIN generates the highest EPS (5.20) and NHFIL generates the lowest EPS (1.71) and overall it has an increasing trend from 2016 to 2019. It is a good sign for NBFIs. [See Appendix Table-04].

Institution Size/ Total Assets: The term asset means anything that can generate business for a company. But for any financial institution's assets means financial assets. It shows the financial strength of a company (Gitman, 2020). Here the calculated result of total assets shows that LBFL maintains the highest level of total assets (5850.75 million) and IPDC maintains the lowest level of total assets (2459.75 million). But for the growth rate DBH is in the highest position (55\%) whereas PLFSL is in lowest the position $(-12 \%)$ during the selected period. [See Appendix Table-05].

Institution Size/ Total Owners' Equity: Equity is essentially the owner's interest in the company's assets. It is what remains for the owner once he has deducted all liabilities from the assets (Gitman, 2020). Here the calculated result of total equity shows that LBFL maintains the highest level of total equity (1393 million) and PLFSL maintains the lowest level of total equity (1126.75 million). But for the growth rate ICB is in the highest position (24.86\%) whereas PLFSL is in lowest the position (-9.46) during the selected period. [See Appendix Table-06].

Current Ratio: Current ratio is an indicator that specifies the firm's ability to pay its current liability with its current assets. It measures the financial health of a company based on its liquidity (Besley, 2017). Here the calculated result for current ratio shows LBFL has the highest current ratio (12.76) and PLFSL has the lowest current ratio (2.92) and overall it shows a fluctuation trend from 2016 to 2019. It is not a good sign for NBFIs. [See Appendix Table-07].

Capital Ratio: The term capital ratio means the extent of using the equities and retaining profits for a financial institution to its operations. It represents the percentage of owners' equity in the total assets of any financial institutions (Besley, 2017). Here the calculated result for capital ratio 
shows DBH has the highest capital ratio (70.34) and IDLC has the lowest capital ratio (22.05) and overall it shows a fluctuation trend from 2016 to 2019 which is not a good sign for NBFIs [See Appendix Table-08].

Non-Preforming Loan (NPL): A non-performing loan (NPL) is a loan where the borrower is in default and has not paid the monthly payment of principal and interest for a certain amount. Nonperforming loans arise when borrowers lack the money to make repayments or are in situations that make it difficult for them to continue to make repayments (Rose, 2016). Here the calculated result for non-performing loan shows LBFL has the highest NPL (166.75 million) and IPDC has the lowest NPL (88.25 million) and overall it shows an increasing trend from 2016 to 2019 which is an alarming sign for NBFIs [See Appendix Table-09].

Interest Coverage Ratio (ICR): The term interest coverage ratio is a debt and the profitability ratio. It is used to determine the capacity of a company to pay interest on its outstanding debt. Interest coverage ratio is calculated by dividing a company's EBIT by its interest expense during a given period (Besley, 2017). Here the calculated result of interest coverage ratio shows that most of the companies are financially capable to pay their financial obligation. Here LBFL has the highest interest coverage ratio (2.12) and GSPFIN has the lowest interest coverage ratio (1.09) [See Appendix Table-10].

COMPARISON OF FINANCIAL PERFORMANCE OF INVESTMENT BANK

To evaluate the market position of NBFIs scores is assigned on the basis of financial ratio of different NBFIs in Bangladesh. The scoring system is based on the performance of different ratios. The best performer will scored from 1 and the worst performer will be scored with 9 . Here the score is given by

$1=$ Best Performer

2

$9=$ Worst Performer

If any value not available, in that case it will be scored by 9 for undesirable performance.

The comparison table is available in the appendix section. [See Appendix Table-11].

\section{RECOMMENDATIONS}

As NBFIs are one of the major sources of funds for the corporations so it contributes a lot to the economic development of the country. In Bangladesh the operation of sector is developing gradually. Based on the calculated result, it can be said that the performance for most of NBFIs in Bangladesh in continuously improving and they are playing a significant role in the market.

Based on ROA, ROE and ROCE the financial performance of the NBFIs shows an increasing trend which is a good sign for this industry. Based on EPS the financial performance of NBFIs also shows an increasing trend but for current ratio, capital ratio it shows a fluctuating trend which means that at any time it can go downward. So to overcome this situation they have to be more efficient to utilize their funds.

One of the major findings of this study is the non-performing (NPL) shows an increasing trend of NBFIs. NPL creates obstacle for the development both for the company and also for the economy. Selecting the adverse loan was the main reason to increase the non- 
performing loan. So to reduce the amount they have to be careful in loan distribution and take proper initiative to collect the existing loans.

In Bangladesh the main sources of generating earning for NBFIs is to provide loans and investing in capital market. Although in recent time performance of capital market is good but still it follows a huge fluctuations. So to be more competitive and to compete with banks they have to identify others options to invest funds and generate more secured income.

\section{CONCLUSION}

This study focuses to analyze the efficiency of NBFIs in Bangladesh within the period from 2019 to 2019. For this it has applied different types of performance measurement tools and techniques. Different types of ratios are used to analyze the performance of NBFIs in Bangladesh. Finally, based on their performances a rank has been created. This study says that NBFIs in Bangladesh are doing well for some ratios while for others it has to improve their performance. The main area where they have to improve is the loan selection. They have to reduce the number of adverse loan selection. At the same time they have to identify other income generating areas to be more competitive.

Although there are a lot of obstacle NBFIs has a huge scope to develop themselves. Bangladesh is moving to a developing country from under developed country and it has become possible for the economic revolution. So NBFIs can take the advantage of this revolution. For this they need to build a strong brand image by providing efficient services to their customers. So in the coming years they have a huge potential to perform. Due to the unavailability of data this study compiles the results of using only nine NBFIs which is a major limitation of this study. In future, by incorporating other NBFIs and other financial measure more accurate results can be created and that is the scope for future research of this study. This study will help the managers to take more accurate decisions related to their operations and the investors to take their investment decision in the capital market.

\section{REFERENCES}

Akber, S. M. (2019). Relationship between profitability and non-performing loan and a comparative financial performance analysis of shari'ah based banks of Bangladesh. Indian Journal of Finance and Banking, 3(2), 32-42.

Akber, S. M. \& Dey, A. (2020). Evaluation of the financial performance between traditional private commercial banks and Islamic banks in Bangladesh. International Journal of Islamic Banking and Finance Research, 4(2), 1-10.

Almumani, M. A. (2014). A comparison of financial performance of Saudi banks. Asian Journal of Research in Banking and Finance, 4(2), 20-29.

Alsamaree, A. H. (2013). Financial ratios and performance of banks. Journal of Research on International Business and Management, 3(1), 17-19.

Avkiran, N. (1995). Developing an instrument to measure customer service quality in branch banking. International Journal of Bank's marketing, 12(6), 10-18. 
Besley, S. \& Bringham, E.F. (2017). Essentials of managerial finance. $14^{\text {th }}$ Edition, SouthWestern: Thomson Higher Education.

Diamond, D. D. P. (1983). Bank runs, deposit insurance and liquidity. Journal of political Economy, 91(3), 41-49.

Elizabeth, D. E. G. (2004). Efficiency customer service and financial performance among Australian financial institutions. International Journal of Bank Marketing, 22(5), 31-42.

Fukuyama, H. (1995). Measuring efficiency and productivity growth in Japanese Banking: A nonparametric Approach. Journal of Applied Financial Economics, 3(2), 95-107.

Gitman,L.J., Zutter, C.H., \& Smart, S.B. (2020). Principles of managerial finance. $15^{\text {th }}$ Edition, New York: Pearson PLC.

Madura, J. (2018). Financial institutions and markets, $11^{\text {th }}$ Edition, New York: Pearson PLC.

Miskhin, F. (2019). The economics of money, banking and financial markets. $11^{\text {th }}$ Edition, New York: Pearson PLC.

Raza, A., \& Farhan, M. (2011). A comparison of financial performance in investment banking sector in Pakistan. International Journal of Business and Social Science, 2(9), 35-45.

Rose, P. (2016). Commercial bank management. $4^{\text {th }}$ Edition. New York: McGraw-Hill.

Tarawneh, M. (2006). A comparison of financial performance in the banking sector: Some Evidence from Omani Commercial banks. International Research Journal of Finance and Economics, 3(1), 21-31.

Tandon, D., Chaturvedi, A., \& Vidyarthi, H. (2019). Non-performing assets and profitability of Indian banks: an econometric study. International Journal of Business Competition and Growth, 6(1), 60-76.

\section{APPENDICES}

\section{Appendix A: Table 1. Return on Asset (ROA)}

\begin{tabular}{|c|c|c|c|c|c|}
\hline Banks/Year & $2016(\%)$ & $2017(\%)$ & $2018(\%)$ & $2019(\%)$ & $\begin{array}{c}\text { Average } \\
(\%)\end{array}$ \\
\hline LBFL & 11.31 & 12.91 & 13.06 & 13.30 & 12.65 \\
\hline IDLC & 14.54 & 10.68 & 13.68 & 14.95 & 13.46 \\
\hline BIFC & 11.12 & 12.85 & 10.86 & 5.70 & 10.13 \\
\hline GSPFIN & 2.41 & 6.02 & 5.64 & 6.72 & 5.20 \\
\hline DBH & 4.01 & 3.25 & 5.71 & 5.89 & 4.72 \\
\hline ICB & 2.47 & 4.28 & 4.32 & 5.53 & 4.15 \\
\hline NHFIL & 2.44 & 3.93 & 4.68 & 5.79 & 4.21 \\
\hline
\end{tabular}




\begin{tabular}{|c|c|c|c|c|c|}
\hline PLFSL & 2.98 & 3.77 & 3.46 & 4.06 & 3.57 \\
\hline IPDC & 4.96 & 6.30 & 6.11 & 7.30 & 6.17 \\
\hline Average & 6.25 & 7.11 & 7.50 & 7.69 & 7.14 \\
\hline
\end{tabular}

Source: Annual report of NBFIS' (2016-2019)

\section{Appendix B: Table 2. Return on Equity (ROE)}

\begin{tabular}{|c|c|c|c|c|c|}
\hline Banks/Year & $2016(\%)$ & $2017(\%)$ & $2018(\%)$ & $2019(\%)$ & $\begin{array}{c}\text { Average } \\
(\%)\end{array}$ \\
\hline LBFL & 12.29 & 13.89 & 14.04 & 14.28 & 13.63 \\
\hline IDLC & 15.3 & 11.44 & 14.44 & 15.71 & 14.22 \\
\hline BIFC & 12.12 & 13.85 & 11.86 & 6.7 & 11.13 \\
\hline GSPFIN & 3.91 & 7.52 & 7.14 & 8.22 & 6.70 \\
\hline DBH & 5.11 & 4.35 & 6.81 & 6.99 & 5.82 \\
\hline ICB & 3.29 & 5.1 & 5.14 & 6.35 & 4.97 \\
\hline NHFIL & 3.79 & 5.28 & 6.03 & 7.14 & 5.56 \\
\hline PLFSL & 4.04 & 4.83 & 4.52 & 5.12 & 4.63 \\
\hline IPDC & 6.31 & 7.65 & 7.46 & 8.65 & 7.52 \\
\hline Average & 7.35 & 8.21 & 8.60 & 8.80 & 8.24 \\
\hline
\end{tabular}

Source: Annual report of NBFIS' (2016-2019)

\section{Appendix C: Table 3. Return on Capital Employed (ROCE)}

\begin{tabular}{|c|c|c|c|c|c|}
\hline Banks/Year & $2016(\%)$ & $2017(\%)$ & $2018(\%)$ & $2019(\%)$ & $\begin{array}{c}\text { Average } \\
(\%)\end{array}$ \\
\hline LBFL & 14.79 & 6.39 & 6.54 & 7.18 & 8.73 \\
\hline IDLC & 18.02 & 14.16 & 17.16 & 18.83 & 17.04 \\
\hline BIFC & 14.6 & 16.33 & 14.34 & 9.58 & 13.71 \\
\hline GSPFIN & 5.89 & 9.5 & 9.12 & 10.6 & 8.78 \\
\hline DBH & 7.49 & 6.73 & 9.19 & 9.77 & 8.30 \\
\hline ICB & 5.95 & 7.76 & 7.8 & 9.41 & 7.73 \\
\hline NHFIL & 5.92 & 7.41 & 8.16 & 9.67 & 7.79 \\
\hline PLFSL & 6.46 & 7.25 & 6.94 & 7.94 & 7.15 \\
\hline IPDC & 8.44 & 9.78 & 9.59 & 11.18 & 9.75 \\
\hline Average & 9.73 & 9.48 & 9.87 & 10.46 & 9.89 \\
\hline
\end{tabular}

Source: Annual report of NBFIS' (2016-2019)

\section{Appendix D: Table 4. Earnings per Share (EPS)}

\begin{tabular}{|c|c|c|c|c|c|c|}
\hline Banks/Year & $2016(\%)$ & $2017(\%)$ & $2018(\%)$ & $2019(\%)$ & Trend & $\begin{array}{c}\text { Average } \\
(\%)\end{array}$ \\
\hline LBFL & $\mathbf{3 . 3}$ & $\mathbf{3 . 3 5}$ & $\mathbf{3 . 5}$ & $\mathbf{4 . 0 5}$ & 22.73 & 3.55 \\
\hline IDLC & 3.54 & 3.68 & 3.75 & 3.95 & 11.58 & 3.73 \\
\hline BIFC & 2.12 & 2.85 & 2.86 & 3.20 & 50.94 & 2.76 \\
\hline GSPFIN & 2.41 & 6.02 & 5.64 & 6.72 & 178.84 & 5.20 \\
\hline
\end{tabular}




\begin{tabular}{|c|c|c|c|c|c|c|}
\hline DBH & 2.51 & 2.75 & 3.21 & 3.39 & 35.06 & 2.97 \\
\hline ICB & 1.47 & 1.28 & 1.32 & 2.53 & 72.11 & 1.65 \\
\hline NHFIL & 1.44 & 1.93 & 1.68 & 1.79 & 24.31 & 1.71 \\
\hline PLFSL & 1.98 & 1.77 & 1.46 & 1.06 & -46.46 & 1.57 \\
\hline IPDC & 3.76 & 3.10 & 2.91 & 3.10 & -17.55 & 3.22 \\
\hline Average & 2.50 & 2.97 & 2.93 & 3.31 & & 2.93 \\
\hline
\end{tabular}

Source: Annual report of NBFIS' (2016-2019)

\section{Appendix E: Table 5. Institution Size/ Total Assets}

\begin{tabular}{|c|c|c|c|c|c|c|}
\hline Banks/Year & $\begin{array}{c}2016 \\
\text { TK(Million) }\end{array}$ & $\begin{array}{c}2017 \\
\text { TK(Million) }\end{array}$ & $\begin{array}{c}2018 \\
\text { TK(Million) }\end{array}$ & $\begin{array}{c}2019 \\
\text { TK(Million) }\end{array}$ & $\begin{array}{c}\text { Average } \\
\text { Growth } \\
\%\end{array}$ & $\begin{array}{c}\text { Average } \\
\text { TK(Million) }\end{array}$ \\
\hline LBFL & 5576 & 5477 & 6245 & 6105 & 9.49 & 5850.75 \\
\hline IDLC & 5719 & 5521 & 5599 & 6068 & 6.10 & 5726.75 \\
\hline BIFC & 4533 & 4953 & 4912 & 5295 & 16.81 & 4923.25 \\
\hline GSPFIN & 5709 & 5511 & 5589 & 6058 & 6.11 & 5716.75 \\
\hline DBH & 2915 & 3032 & 4414 & 4537 & 55.64 & 3724.50 \\
\hline ICB & 33624 & 4004 & 4458 & 4604 & 27.04 & 4172.50 \\
\hline NHFIL & 2324 & 2327 & 2739 & 2990 & 28.66 & 2595.00 \\
\hline PLFSL & 2647 & 3050 & 2847 & 2328 & -12.05 & 2718.00 \\
\hline IPDC & 2446 & 2462 & 2464 & 2467 & & 2459.75 \\
\hline
\end{tabular}

Source: Annual report of NBFIS' (2016-2019)

\section{Appendix F: Table 6. Institution Size/ Total Owners' Equity}

\begin{tabular}{|c|c|c|c|c|c|c|}
\hline Banks/Year & $\begin{array}{c}2016 \\
\text { TK(Million) }\end{array}$ & $\begin{array}{c}2017 \\
\text { TK(Million) }\end{array}$ & $\begin{array}{c}2018 \\
\text { TK(Million) }\end{array}$ & $\begin{array}{c}2019 \\
\text { TK(Million) }\end{array}$ & $\begin{array}{c}\text { Average } \\
\text { growth \% }\end{array}$ & $\begin{array}{c}\text { Average } \\
\text { TK } \\
\text { (Million) }\end{array}$ \\
\hline LBFL & 1337 & 1310 & 1435 & 1490 & 11.44 & 1393.00 \\
\hline IDLC & 1260 & 1303 & 1289 & 1343 & 6.59 & 1298.75 \\
\hline BIFC & 1287 & 1326 & 1266 & 1240 & -3.65 & 1279.75 \\
\hline GSPFIN & 993 & 1115 & 1289 & 1059 & 6.65 & 1114.00 \\
\hline DBH & 1098 & 1112 & 1250 & 1257 & 14.48 & 1179.25 \\
\hline ICB & 1633 & 1767 & 1947 & 2039 & 24.86 & 1846.50 \\
\hline NHFIL & 1023 & 1202 & 1252 & 1273 & 24.44 & 1187.50 \\
\hline PLFSL & 1152 & 1086 & 1226 & 1043 & -9.46 & 1126.75 \\
\hline IPDC & 1324 & 1342 & 1319 & 1315 & -0.68 & 1325.00 \\
\hline
\end{tabular}

Source: Annual report of NBFIS' (2016-2019)

\section{Appendix G: Table 7. Current Ratio}

\begin{tabular}{|c|c|c|c|c|c|}
\hline Banks/Year & $2016(\%)$ & $2017(\%)$ & $2018(\%)$ & $2019(\%)$ & Average(Times) \\
\hline LBFL & 11.75 & 16.50 & 11.95 & 10.83 & 12.76 \\
\hline IDLC & 11.33 & 12.30 & 12.62 & 13.45 & 12.43 \\
\hline
\end{tabular}




\begin{tabular}{|c|c|c|c|c|c|}
\hline BIFC & 1.53 & 1.58 & 1.50 & 1.73 & 1.59 \\
\hline GSPFIN & 2.48 & 2.55 & 2.50 & 2.61 & 2.54 \\
\hline DBH & 19.93 & 13.80 & 5.71 & 3.78 & 10.81 \\
\hline ICB & 1.31 & 2.85 & 2.85 & 3.10 & 2.53 \\
\hline NHFIL & 7.95 & 10.88 & 7.57 & 8.73 & 8.78 \\
\hline PLFSL & 2.93 & 2.85 & 2.82 & 3.07 & 2.92 \\
\hline IPDC & 12.93 & 13.59 & 16.67 & 16.82 & 15.00 \\
\hline Average & 8.02 & 8.54 & 7.13 & 7.12 & 7.70 \\
\hline
\end{tabular}

Source: Annual report of NBFIS' (2016-2019)

\section{Appendix H: Table 8. Capital Ratio}

\begin{tabular}{|c|c|c|c|c|c|}
\hline Banks/Year & $2016(\%)$ & $2017(\%)$ & $2018(\%)$ & $2019(\%)$ & Average(Times) \\
\hline LBFL & 9.74 & 18.45 & 33.99 & 30.00 & 23.05 \\
\hline IDLC & 11.50 & 12.24 & 9.70 & 54.76 & 22.05 \\
\hline BIFC & 35.57 & 35.65 & 30.77 & 29.17 & 32.79 \\
\hline GSPFIN & 23.73 & 27.46 & 30.86 & 23.53 & 26.40 \\
\hline DBH & 56.42 & 71.54 & 77.92 & 75.47 & 70.34 \\
\hline ICB & 50.76 & 46.33 & 45.80 & 46.45 & 47.34 \\
\hline NHFIL & 57.92 & 57.63 & 56.30 & 56.77 & 57.16 \\
\hline PLFSL & 43.99 & 41.05 & 43.84 & 44.32 & 43.30 \\
\hline IPDC & 60.91 & 59.50 & 59.20 & 58.40 & 59.50 \\
\hline Average & 38.95 & 41.09 & 43.15 & 46.54 & 42.43 \\
\hline
\end{tabular}

Source: Annual report of NBFIS' (2016-2019)

\section{Appendix I: Table 9. Non-Preforming loan}

\begin{tabular}{|c|c|c|c|c|c|}
\hline Banks/Year & $\begin{array}{c}2016 \\
\text { TK(Million) }\end{array}$ & $\begin{array}{c}2017 \\
\text { TK(Million) }\end{array}$ & $\begin{array}{c}2018 \\
\text { TK(Million) }\end{array}$ & $\begin{array}{c}2019 \\
\text { TK(Million) }\end{array}$ & $\begin{array}{c}\text { Average } \\
\text { TK(Million) }\end{array}$ \\
\hline LBFL & 140 & 158 & 185 & 184 & 166.75 \\
\hline IDLC & 127 & 115 & 188 & 150 & 145.00 \\
\hline BIFC & 98 & 116 & 114 & 118 & 111.50 \\
\hline GSPFIN & 95 & 98 & 102 & 106 & 100.25 \\
\hline DBH & 86 & 88 & 92 & 98 & 91.00 \\
\hline ICB & 130 & 138 & 144 & 151 & 140.75 \\
\hline NHFIL & 95 & 102 & 108 & 116 & 105.25 \\
\hline PLFSL & 187 & 206 & 202 & 198 & 198.25 \\
\hline IPDC & 84 & 86 & 89 & 94 & 88.25 \\
\hline Average & 116.00 & 123.00 & 136.00 & 135.00 & 127.00 \\
\hline
\end{tabular}

Source: Annual report of NBFIS' (2016-2019)

\section{Appendix J: Table 10: Interest Coverage Ratio}

\begin{tabular}{|c|c|c|c|c|c|}
\hline Banks/Year & $2016(\%)$ & $2017(\%)$ & $2018(\%)$ & $2019(\%)$ & Average(Times) \\
\hline LBFL & 1.85 & 1.97 & 2.28 & 2.39 & 2.12 \\
\hline
\end{tabular}




\begin{tabular}{|c|c|c|c|c|c|}
\hline IDLC & 1.41 & 1.39 & 1.68 & 1.94 & 1.61 \\
\hline BIFC & 1.58 & 2.01 & 1.73 & 1.89 & 1.80 \\
\hline GSPFIN & 1.01 & 1.26 & 1.55 & 0.55 & 1.09 \\
\hline DBH & 1.13 & 1.25 & 1.39 & 1.48 & 1.31 \\
\hline ICB & 1.42 & 1.60 & 1.94 & 1.86 & 1.71 \\
\hline NHFIL & 1.67 & 1.74 & 1.05 & 1.06 & 1.38 \\
\hline PLFSL & 1.79 & 1.84 & 1.32 & 1.28 & 1.56 \\
\hline IPDC & 1.87 & 2.89 & 2.95 & 3.14 & 2.71 \\
\hline Average & 1.53 & 1.77 & 1.77 & 1.73 & 1.70 \\
\hline
\end{tabular}

Source: Annual report of NBFIS' (2016-2019)

\section{Appendix K: Table 11: Ranks of Investment Banks Based on Financial Performance}

\begin{tabular}{|l|l|l|l|l|l|l|l|l|l|l|l|}
\hline \multirow{2}{*}{$\begin{array}{l}\text { Performance } \\
\text { Indicators }\end{array}$} & \multicolumn{9}{|c|}{ Investment Banks } \\
\cline { 2 - 12 } & LBFL & IDLC & BIFC & GSPFIN & DBH & ICB & NHFIL & PLFSL & IPDC \\
\hline Financial Measures & 2 & 1 & 3 & 5 & 6 & 8 & 7 & 9 & 3 \\
\hline ROA & 2 & 1 & 3 & 5 & 6 & 8 & 7 & 9 & 4 \\
\hline ROE & 4 & 1 & 2 & 3 & 5 & 7 & 6 & 8 & 9 \\
\hline ROCE & 3 & 2 & 6 & 1 & 5 & 8 & 7 & 9 & 4 \\
\hline EPS & 2 & 3 & 5 & 4 & 4 & 1 & 8 & 7 & 9 \\
\hline Total Assets & 2 & 4 & 5 & 9 & 7 & 1 & 6 & 8 & 3 \\
\hline Total Equity & 2 & 3 & 9 & 7 & 4 & 8 & 5 & 6 & 1 \\
\hline $\begin{array}{l}\text { Current } \\
\text { ratio }\end{array}$ & 8 & 9 & 6 & 7 & 1 & 4 & 3 & 5 & 2 \\
\hline $\begin{array}{l}\text { Capital } \\
\text { Ratio }\end{array}$ & 8 & 7 & 5 & 3 & 2 & 6 & 4 & 9 & 1 \\
\hline NPL & 8 & 5 & 3 & 9 & 8 & 4 & 7 & 6 & 1 \\
\hline $\begin{array}{l}\text { Interest } \\
\text { Coverage }\end{array}$ & 2 & & & & & & & & 5 & \\
\hline
\end{tabular}

Source: Authors Own Contribution

\section{Appendix L: Table 12: Samples used in the study}

\begin{tabular}{|c|c|l|}
\hline SL. & Symbol & \multicolumn{1}{|c|}{ Full Name } \\
\hline 1 & LBFL & LankaBangla Finance Ltd. \\
\hline 2 & IDLC & IDLC Finance Ltd. \\
\hline 3 & BIFC & Bangladesh Industrial Fin. Co. Ltd. \\
\hline 4 & GSPFIN & GSP Finance Company (Bangladesh) limited \\
\hline 5 & DBH & Delat Brac Housing Finance Corp. Ltd. \\
\hline 6 & ICB & Investment Corporation of Bangladesh \\
\hline 7 & NHFIL & National Housing Fin. and Inv. Ltd. \\
\hline 8 & PLFSL & Peoples Leasing and Fin. Services Ltd. \\
\hline 9 & IPDC & IPDC Finance Limited. \\
\hline
\end{tabular}




\author{
AUTHOR CONTRIBUTIONS \\ Conceptualization: S. M. Akber, Dhiman Barua \\ Data curation: S. M. Akber, Dhiman Barua \\ Formal analysis: S. M. Akber \\ Funding Acquisition: S. M. Akber, Dhiman Barua \\ Project Administration: S. M. Akber \\ Software: S. M. Akber \\ Validation: S. M. Akber, Dhiman Barua \\ Writing - Original Draft: S. M. Akber, Dhiman Barua \\ Writing - Review \& Editing: S. M. Akber, Dhiman Barua

\section{CONFLICT OF INTEREST STATEMENT} \\ The authors declare that they have no competing interests.
}

\title{
COPYRIGHTS
}

Copyright for this article is retained by the author(s), with first publication rights granted to the journal. This is an open-access article distributed under the terms and conditions of the Creative Commons Attribution license (https://creativecommons.org/licenses/by/4.0). 